\title{
Paracetamol poisoning in children
}

\section{Trovanje paracetamolom u djece}

\author{
Arijan Verbić*, Kristina Lah Tomulić, Ivona Butorac Ahel, Ana Milardović
}

Klinika za pedijatriju, KBC Rijeka, Rijeka

"Corresponding author:

Arijan Verbić, dr. med.

Klinika za pedijatriju KBC Rijeka

Istarska 43, 51000 Rijeka

e-mail: arijan.verbic@gmail.com

\begin{abstract}
Paracetamol is the most commonly used antipyretic and analgesic in children and the association between paracetamol and hepatotoxicity has been well established. With it's widespread use, it became one of the most common pharmaceuticals associated with both unintentional and intentional poisoning and toxicity. Although therapeutic and unintentional overdosage typically occurs in children, hepatic damage or death due to paracetamol poisoning appears to be rare compared to adults. Despite this fact, paracetamol is currently a major and the most common identifiable cause of acute liver failure in children. Therefore, we bring this review article on well established modes of pathophysiologycal mechanisms of liver damage, current diagnostic and treatment concepts of acute paracetamol poisoning, and special overview of acetylcystein as cornerstone of therapy with proven safety and eficacy in children.
\end{abstract}

Key words: acetylcysteine; children; diagnosis; paracetamol; poisoning; treatment

Sažetak. Paracetamol je najčešće korišteni antipiretik i analgetik u djece i dobro je znana njegova potencijalna hepatotoksičnost. Današnja široka upotreba dovela je do činjenice da je to lijek koji najčešće dovodi do namjernih i nenamjernih otrovanja, kao i jetrene toksičnosti. lako se terapijsko i nenamjerno predoziranje događa tipično u djece, oštećenje jetre i smrt zbog trovanja paracetamolom ipak su rijetki u odnosu na adultnu populaciju. Unatoč tome, paracetamol je trenutno najznačajniji i najčešće identificirani uzrok akutnog jetrenog zatajenja u djece. U tom svjetlu donosimo ovaj pregledni članak o dobro utvrđenim patofiziološkim mehanizmima jetrenog oštećenja i aktualnim konceptima dijagnostike i liječenja akutnog otrovanja paracetamolom, s posebnim osvrtom na acetilcistein kao temeljnu, sigurnu i učinkovitu terapijsku opciju u liječenju djece i adolescenata.

Ključne riječi: acetilcistein; dijagnoza; djeca; liječenje; paracetamol; trovanje

http://hrcak.srce.hr/medicina 


\section{INTRODUCTION}

Extensive medical use of paracetamol began in 1947, and it has become the most commonly used antipyretic and analgesic in children. Paracetamol has an excellent safety profile when administered in proper therapeutic doses, but is one of the most common pharmaceuticals associated with both intentional and unintentional poisoning and toxicity when overdosage occurs. A therapeutic misadventure typically occurs in children younger than 1 year, accidental poisoning (unintentional ingestion) in toddlers and young children with unsupervised access to medications, and older patients may overdose with intent to do self-harm. In children population there are substantial cases of liver injury, liver failure and even several deaths reported each year. The majority of this severe cases are clearly attributable to overdose, with some case reports and case series have suggested that deaths may occur with therapeutic dosing ${ }^{1}$. Also, repeated supratherapeutic doses can cause hepatotoxicity in children with certain risk factors, including decreased oral intake and dehydration, viral infections and malnutrition). In rare cases it also poses the risk for three rare but potentially fatal skin disorders unrelated to dosage: Stevens-Johnson syndrome, toxic epidermal necrolysis, and acute generalized exanthematous pustulosis. The significance of this problem was recognized even by the American Food and Drug Agency (FDA). It is addressing changes to paracetamol-based medications, such as safe daily dose for healthy individuals of all ages, patients with chronic liver disease, patients who concurrently drink alcohol, appropriate dose needed for efficacy, package size restrictions and current formulations of paracetamol-narcotic combination drugs. Nevertheless the paracetamol poisoning remains the most important recognizable factor of acute liver failure in children, and pediatricians in hospitals, as well as primary health care providers should be well informed of the toxic doses, course of liver injury and treatment options of acute paracetamol poisoning.

\section{EPIDEMIOLOGY}

Paracetamol remains a major cause of overdose in children throughout the world. In the United States, pediatric paracetamol exposures account for approximately 30,000 reports to the National Poison Data System annually. Survey data indicate that approximately $26 \%$ of children younger than 24 months and approximately $10 \%$ of children between 2 and 5 years have received at least one dose of paracetamol in the past week. Among these millions of exposures, there are several cases of liver injury, liver failure and a few deaths reported each year ${ }^{2,3}$. Heard et al made a search study to identify and validate reports of liver injury or death in children younger than 6

Paracetamol is the most commonly used antipyretic and analgesic worldwide and a major identifiable cause of acute liver failure in children.

years of age following repeated therapeutic doses of paracetamol. It yielded 2531 reports of adverse events associated with paracetamol use. From these cases, they identified 76 cases of hepatic injury and 26 deaths associated with repeated paracetamol administration ${ }^{4}$. There were 6 cases of hepatic abnormalities and no deaths associated with therapeutic doses. All of the deaths and all but 6 cases of hepatic abnormalities involved doses of paracetamol greater than $75 \mathrm{mg} / \mathrm{kg} /$ day. Another recent systematic reviews reported no cases of hepatic injury among 32,414 children who received adequate therapeutic doses of paracetamol, and those studies showed that there are very few cases of children who develop hepatic abnormalities when given repeated doses of paracetamol ${ }^{5,6}$.

\section{PATHOPHYSIOLOGY}

Hepatotoxicity is caused by the formation of a toxic metabolite, $\mathrm{N}$-acetyl-pbenzoquinoneimine (NAPQI). In therapeutic doses, most of the drug (> $90 \%$ ) is metabolized via glucuronidation and sulfation. Approximately $5 \%$ of paracetamol is metabolized to NAPQI by the hepatic enzyme cytochrome P450 2E1 (CYP2E1). NAPQI is then conjugated by glutathione to form the benign metabolite, mercapturic acid, which is excreted in the urine (Figure 1). As long as sufficient glutathione is present the liver is protected, but hepatotoxicity develops when large doses of pa- 


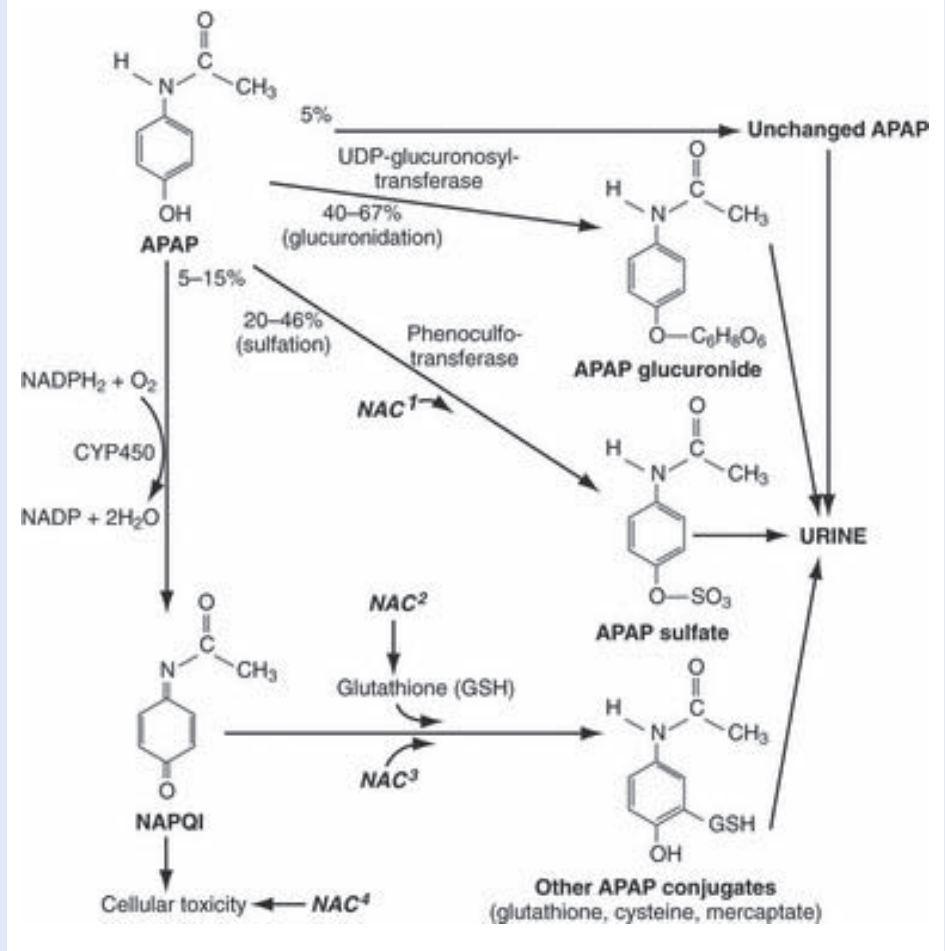

Figure 1. Paracetamol metabolism and $\mathrm{N}$-acetylcysteine(NAC) mechanism of action (modified from reference 25)

Figure legend: $\mathrm{N}$-acetyl-p-aminophenol (APAP) is the active component of paracetamol; NAC1 enhances sulfation; NAC2 serves as a glutathione (GSH) precursor; NAC3 is a GSH substitute; NAC4 may reduce systemic toxicity. NAPQI, $\mathrm{N}$-acetyl-p-benzoquinone imine.

racetamol overwhelm and deplete available glutathione stores, leading to reduced clearance of the toxic metabolite. Accumulation of the toxic metabolite can then exert untoward effect of oxidative stress with mitochondrial dysfunction, cytokines and chemokines disbalance which leads to cell death alterations in hepatic blood flow, inflammation, and liver necrosis ${ }^{7}$.

Children younger than six years of age appear to be less susceptible to hepatotoxicity due to greater capacity for conjugation with sulfate and increased supply and regeneration of glutathione ${ }^{6}$, with adult patterns of metabolism are reached between 10 and 12 years of age. Pathophysiology of liver damage is important for understanding significance and pivotal role of acetylcysteine (also known as $\mathrm{N}$-acetylcysteine) as primary therapeutic option. It prevents hepatic injury primarily by restoring hepatic glutathione, scavenging of free radicals or changes in hepatic blood flow ${ }^{8}$ (Figure 1).

\section{DIAGNOSIS}

Toxic dose is defined empirically as a dose that is known to cause toxicity. The key points to diagnosis of potential paracetamol toxicity is obtaining a history of paracetamol ingestion, and the measurement of a potentially toxic serum paracetamol concentration. Keeping in mind that unintentional ingestion in young children is leading mechanism of paracetamol poisoning, all children who present with hepatic dysfunction of unknown etiology should raise suspicion of paracetamol poisoning. Consensus guidelines developed by the American Association of Poison Control Centers and based upon observational studies suggest that children and adolescents who meet the following criteria after acute overdose be referred to an emergency department for evaluation of paracetamol toxicity $^{9}$ :

- Exposure to $200 \mathrm{mg} / \mathrm{kg}$ or $10 \mathrm{~g}$, whichever is LESS, acutely or over 24 hours

- Ingestion of an unknown amount of paracetamol

- Ingestion of paracetamol with intent for self harm

- Known exposure to paracetamol with signs of toxicity (eg, vomiting, right upper quadrant pain, altered mental status)

Children and adolescents who meet the following criteria should be referred to an emergency department for evaluation of paracetamol toxicity after the following supratherapeutic exposures:

- $150 \mathrm{mg} / \mathrm{kg}$ or $6 \mathrm{~g}$, whichever is LESS, per 24 hour period over 48 hours

- In children less than six years of age, $100 \mathrm{mg} /$ $\mathrm{kg}$ or more per 24 hour period for the preceding 72 hours or longer

- Children with conditions that predispose to paracetamol toxicity (eg, fasting, liver disease) with an ingestion of $100 \mathrm{mg} / \mathrm{kg}$ or $4 \mathrm{~g}$, whichever is less, per day.

\section{Clinical course}

After ingestion paracetamol is rapidly and completely absorbed in stomach and small intestine reaching peak serum concentrations within four hours of oral intake. One should know that time and extension could be altered with type and ap- 
plication form of preparation(rectal, intravenous, slow-release), delayed gastric emptying, following massive overdose or with coingestions in intentional poisoning.

The clinical course of acute single-dose exposures is often divided into four sequential stages $^{10,11}$ :

- Stage I (up to 24 hours after overdose) Asymptomatic but less commonly: nausea, vomiting, and, in patients with very large doses, lethargy and malaise.

- Stage II (24 to 72 hours after overdose) - Right upper quadrant pain, elevation in liver enzymes, prothrombin time (PT) and international normalized ratio of PT, and, in severe cases, evidence of nephrotoxicity (elevated blood urea nitrogen, creatinine, oliguria) and/or pancreatitis (elevated serum amylase, lipase)

- Stage III (72 to 96 hours) - Evidence of liver failure and, in severe cases, renal failure and multi-organ failure; death most commonly occurs in this stage

- Stage IV (4 to 14 days) - Recovery

\section{Labaratory evaluation}

The serum paracetamol concentration is of the paramount for diagnosis and treatment, because of the delay in onset of clinical manifestations of toxicity, even in the absence of symptoms. A level of paracetamol concentration 4 hours post ingestion of greater than $150 \mathrm{mcg} / \mathrm{mL}$ (> $993 \mu \mathrm{mol} / \mathrm{L}$ ) reflects possible toxicity. Aspartate aminotransferase (AST) and alanine aminotransferase (ALT), serum bilirubin and alkaline phosphatase levels should be obtained. They begin to rise within 12 hours in severe overdose, normally 24 hours after an acute ingestion and peak at about 72 hours (Figure 2). Toxicity is defined as serum AST or ALT levels greater than $1000 \mathrm{IU} / \mathrm{L}$, with rapid progression of transaminase values to $3000 \mathrm{IU} / \mathrm{L}$ or higher reflecting worsening hepatotoxicity. Hepatic synthetic and renal function tests should be addressed since renal failure often occurs with hepatic failure, and becomes apparent after 48 hours after paracetamol poisoning. Nevertheless prothrombin time (PT), international normalized ratio (INR) prolongation and elevated serum creatinine level are considered as independent predictors of mortality. Obtain a serum glucose level

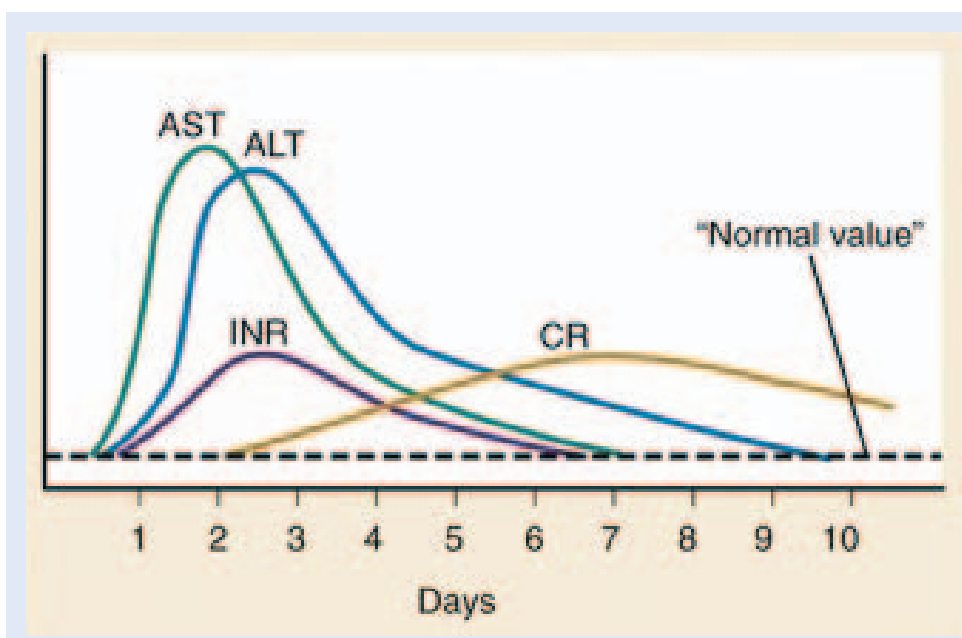

Figure 2. Trends of labaratory values in paracetamol poisoning (modified from reference 26)

to assess for hypoglycemia, a blood type and cross-match in the event of coagulopathy and active bleeding.

\section{TREATMENT}

Children who receive appropriate treatment generally have a good prognosis, particularly when treatment is started within 8 hours of an acute paracetamol ingestion, with hepatotoxicity as low as $10 \%$. Based on observational data from the Pediatric Acute Liver Failure study group, recovery occurred in $94 \%$ of instances of paracetamol overdose in children when treated appropriately $^{12}$. Initial management consist of providing general supportive care of airway, breathing, and circulation, and with administration of activated charcoal ( $1 \mathrm{~g} / \mathrm{kg}$ - maximum dose $50 \mathrm{~g}$ ) to patients presenting within four hours of ingestion of unknown potentially toxic amount of paracetamol. Patients who present for care after four hours are unlikely to benefit from activated charcoal unless agents that slow gastric motility, (opioids, calcium channel blockers, anticholinergic agents) were also ingested.

With understanding mechanisms for paracetamol hepatoxicity, and that compounds with sulphydryl groups (methionine and $\mathrm{N}$-acetylcysteine) could prevent it, Both Rumack \& Matthew (1975) ${ }^{13}$ and Prescott et al (1979) ${ }^{14}$ produced nomograms of plasma paracetamol concentrations (logarithm) vs time using the prognostic correlations obtained 
from adult data. A lower treatment threshold of $50 \%$ of the standard concentration at which treatment would be instigated is recommended for patients children in high risk groups (malnourished or on cytochrome p450 enzyme inducing drugs $)^{15,16}$. Because of low toxicity and potential beneficial effects, even consider early treatment with $\mathrm{N}$-acetylcysteine (NAC) when acetaminophen toxicity is a likely contributor of liver dysfunction ${ }^{17}$.

Treatment is indicated with administering the antidote, NAC in adolescents and children ${ }^{17-20}$ :

Acetylcystein is cornerstone therapy of acute paracetamol poisoning, with proven safety and eficacy in children.

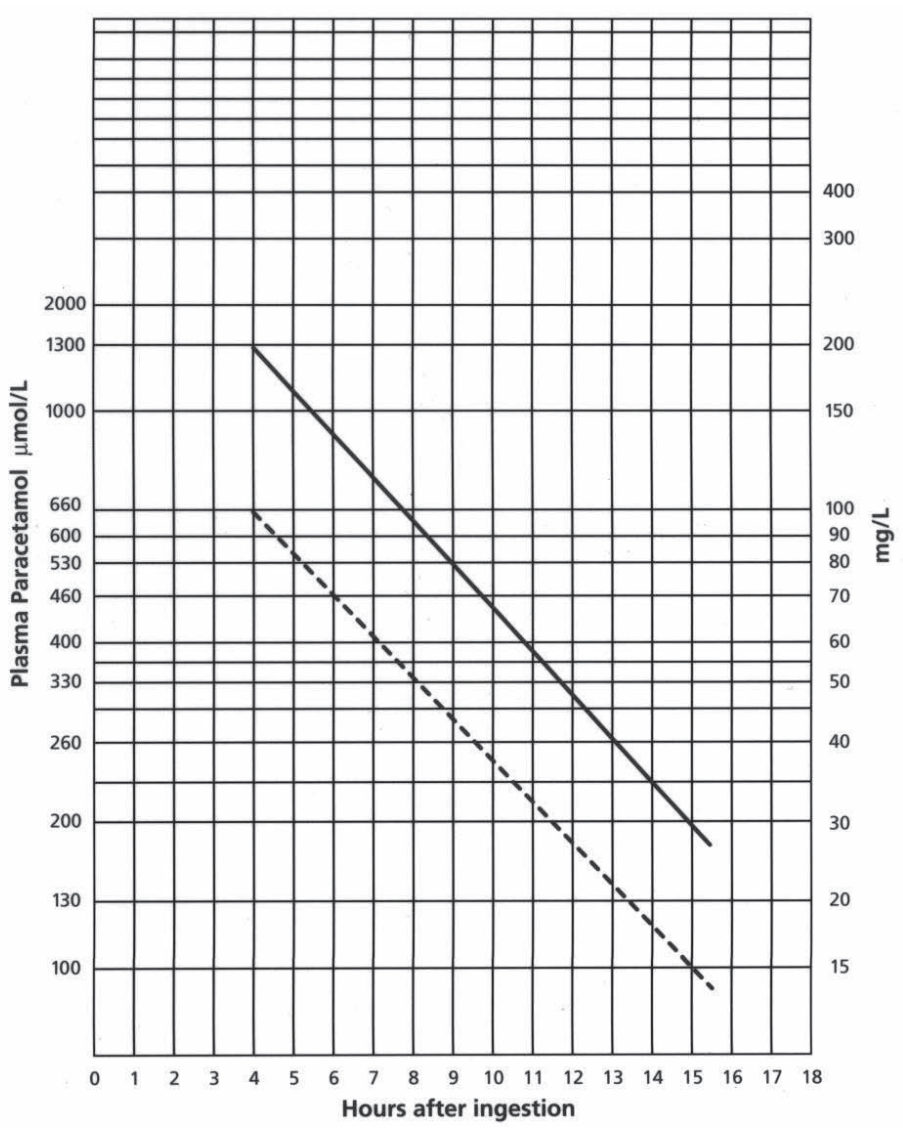

Figure 3. Rumack-Matthew nomogram (modified from reference 14)

Figure legend: Treatment with acetylcysteine should be started: a) Above upper solid line - for all cases; b) Above lower dotted line: 1) in cases of glutathione depletion, 2) in cases where liver macrosomal oxidases have been induced, 3 ) in cases of excess alcohol consumption a) when the plasma paracetamol concentration exceeds the treatment line in the RumackMatthew nomogram (Figure 3);

b) a suspected single ingestion of greater than $150 \mathrm{mg} / \mathrm{kg}$ (7.5 g total dose regardless of weight) in a patient for whom the serum paracetamol concentration will not be available until more than eight hours from the time of the ingestion;

c) patients with an unknown time of ingestion beyond 24 hours and a serum paracetamol concentration > $10 \mathrm{mg} / \mathrm{L}(66 \mu \mathrm{mol} / \mathrm{L})$;

d) patients with delayed presentation (> 24 hours after ingestion) consisting of laboratory evidence of hepatotoxicity (from mildly elevated aminotransferases to fulminant hepatic failure) and a history of excessive paracetamol ingestion.

NAC is most effective when given within 10 hours of paracetamol overdose, but the use of $\mathrm{N}$-acetylcysteine in children with delayed (> 24 hours) presentation of paracetamol intoxication is considered of benefit regarding the use of intravenous NAC in adults which significantly reduced mortality(10). Management of children with chronic paracetamol overdoses is often difficult and does not follow standard recommendations, so it should be provided in consultation with a regional poison control center or medical toxicologist.

Recommended routes and dosing suggest 21 hour intravenous (IV) and the 72 hour oral treatment regimens for $\mathrm{N}$-acetylcysteine. There are minimal differences in efficacy with both routes of administration, as long as the antidote is given within 10 hours. Oral preparation is contraindicated in certain circumstances such as intractable vomiting, aspiration risk due to altered mental status, pancreatitis, bowel obstruction and injury, severe hepatic failure, while anaphylactoid reactions occur more frequently in patients treated with the i.v. preparation, but are very rare.

The regimens for oral or IV administration of NAC $\operatorname{are}^{17-20,21-24}$ :

- Oral - a standard 72-hour oral course of NAC is given as a $140 \mathrm{mg} / \mathrm{kg}$ loading dose followed by 17 doses of $70 \mathrm{mg} / \mathrm{kg}$ every four hours (total dose $1330 \mathrm{mg} / \mathrm{kg}$ ) 
- Intravenous - the 21 hour intravenous (IV) protocol for acetylcysteine treatment suggests a total dose of $300 \mathrm{mg} / \mathrm{kg}$ of NAC is given intravenously delivered over 21 hours based on body weight:

a) Patients $\leq 20 \mathrm{~kg}$ :

Loading dose $-150 \mathrm{mg} / \mathrm{kg}$ in $3 \mathrm{~mL}$ per $\mathrm{kg}$ of diluent given IV over 60 minutes; Second dose - $50 \mathrm{mg} / \mathrm{kg}$ in $7 \mathrm{~mL}$ per $\mathrm{kg}$ of diluent given IV over 4 hours (12.5 mg/kg NAC per hour); Third dose $-100 \mathrm{mg} / \mathrm{kg}$ in $14 \mathrm{~mL}$ per $\mathrm{kg}$ of diluent given IV over 16 hours $(6.25 \mathrm{mg} / \mathrm{kg}$ NAC per hour)

b) Patients $>20$ and $<40 \mathrm{~kg}$ :

Loading dose $-150 \mathrm{mg} / \mathrm{kg}$ in $100 \mathrm{~mL}$ of diluent given IV over 60 minutes; Second dose $50 \mathrm{mg} / \mathrm{kg}$ in $250 \mathrm{~mL}$ of diluent given IV over 4 hours (12.5 mg/kg NAC per hour); Third dose $-100 \mathrm{mg} / \mathrm{kg}$ in $500 \mathrm{~mL}$ of diluent administered over 16 hours ( $6.25 \mathrm{mg} / \mathrm{kg}$ NAC per hour)

c) Patients $\geq 40 \mathrm{~kg}$ may receive IV NAC as recommended for adults:

Loading dose $-150 \mathrm{mg} / \mathrm{kg}$ in $200 \mathrm{ml}$ of diluent over 15 to 60 minutes; Second dose- $50 \mathrm{mg} / \mathrm{kg}$ in $500 \mathrm{ml}$ of diluent over 4 hours; Third dose $100 \mathrm{mg} / \mathrm{kg}$ in $1000 \mathrm{~mL}$ of diluent administered over 16 hours ( $6.25 \mathrm{mg} / \mathrm{kg}$ NAC per hour).

NAC can cause adverse effects which include flushing, itching, rashes, angioedema, bronchospasm, and hypertension. NAC should be stopped and, if necessary, an intravenous antihistamine given. Once any adverse effects have settled, the $\mathrm{NAC}$ can be restarted at a rate of $50 \mathrm{mg} / \mathrm{kg}$ over 4 hours.

\section{Monitoring during treatment}

Serum paracetamol level and ALT should be measured every 12 hours. Elevation in ALT warrants additional testing, and if there is elevation in ALT measure INR every 12 hours. If the patient develops an ALT greater than 1000 international units/L, coagulopathy (ie, INR > 1.5), or encephalopathy, this warrants ICU admission and monitoring of serum bicarbonate, glucose, and creatinine measured every 12 hours $^{18,24}$.

\section{Duration of treatment}

Measure the ALT prior to stopping NAC and continue treatment as long as the ALT is abnormal and remeasure the serum paracetamol concentration prior to stopping NAC to verify that the level is undetectable. Only a small proportion of patients develop severe hepatotoxicity and fulminant hepatic failure. Clinicians should consult a specialist liver unit for advice on the management of patients with liver failure or signs that indicate a poor prognosis.

\section{CONCLUSION}

Paracetamol poisoning is very common in children. Although serious complications are rare, they can have disastrous concequences leading to fulminant hepatic failure and even death. When treated adequately and promptly with acetylcysteine, paracetamol toxicity can be reduced to minimum without any serious side effects. It is very important for a clinician to have a good insight in pathophsiology of toxic paracetamol induced liver failure and mechanisms of action of acetylcysteine, so he could provide optimal evidence based treatment, in order to prevent unwanted morbidity and mortality in children with acute paracetamol poisoning.

Conflicts of interest statement: The authors report no conflicts of interest.

\section{REFERENCES}

1. Prescott LF. Therapeutic misadventure with paracetamol: fact or fiction? Am J Ther 2000;7:99-114.

2. Bronstein AC, Spyker DA, Cantilena LR Jr, Rumack BH, Dart RC. 2010 Annual Report of the American Association of Poison Control Centers' National Poison Data System (NPDS): 28th Annual Report. Clin Toxicol (Phila) 2011;49:910.

3. Vernacchio L, Kelly JP, Kaufman DW, Mitchell AA. Medication use among children $<12$ years of age in the United States: results from the Slone Survey. Pediatrics 2009;124:446-54.

4. Heard K, Bui A, Mlynarchek SL, Green JL, Bond GR, Clark RF et al. Toxicity from repeated doses of acetaminophen in children: assessment of causality and dose in reported cases. Am J Ther 2014;21:174-83.

5. Heard K, Bui A, Mlynarchek SL, Green JL, Bond GR, Clark RF et al. Toxicity from repeated doses of acetaminophen in children: assessment of causality and dose in reported cases. Am J Ther 2014;21:174-83.

6. Lavonas EJ, Reynolds KM, Dart RC. Therapeutic acetaminophen is not associated with liver injury in children: a systematic review. Pediatrics 2010;126:e1430-44.

7. Hinson JA, Roberts DW, James LP. Mechanisms of acetaminophen-induced liver necrosis. Handb Exp Pharmacol 2010;196:369-405. 
8. Penna A, Buchanan N. Paracetamol poisoning in children and hepatotoxicity. Br J Clin Pharmacol 1991; 32:143.

9. Dart RC1, Erdman AR, Olson KR, Christianson G, Manoguerra AS, Chyka PA et al. Acetaminophen poisoning: an evidence-based consensus guideline for out-of-hospital management. Clin Toxicol (Phila) 2006;44:1-18.

10. Heard KJ. Acetylcysteine for acetaminophen poisoning. N Engl J Med 2008;359:285-92.

11. Up to date [Internet]. Heard K, Dart R. Clinical manifestations and diagnosis of acetaminophen (paracetamol) poisoning in children and adolescents. [cited 2016 February 11]. Available from: http://www.uptodate.com/.

12. Squires RH Jr, Shneider BL, Bucuvalas J, Alonso E, Sokol RJ, Narkewicz MR et al. Acute liver failure in children: the first 348 patients in the pediatric acute liver failure study group. J Pediatr 2006;148:652-8.

13. Rumack $\mathrm{BH}$, Matthew $\mathrm{H}$. Acetaminophen poisoning and toxicity. Pediatrics 1975;55:871-6.

14. Prescott LF, Illingworth RN, Critchley JA, Stewart MJ, Adam RD, Proudfoot AT. Intravenous $\mathrm{N}$-acetylcystine: the treatment of choice for paracetamol poisoning. $\mathrm{Br}$ Med J 1979;2:1097-100.

15. Riordan $M$, Rylance G, Berry K. Poisoning in children 2: painkillers. Arch Dis Child 2002;87:397-9.

16. Smilkstein MJ, Knapp GL, Kulig KW, Rumack BH. Efficacy of oral $\mathrm{N}$-acetylcysteine in the treatment of acetaminophen overdose. Analysis of the national multicenter study (1976 to 1985). N Engl J Med 1988;319:1557.

17. American Academy of Pediatrics. Committee on Drugs Acetaminophen toxicity in children. Pediatrics 2001; 108:1020-4.

18. Up to date[Internet]. Heard K, Dart R. Management of acetaminophen (paracetamol) poisoning in children and adolescents. [cited 2016 February 11]. Available from: http://www.uptodate.com/.

19. Zed PJ, Krenzelok EP. Treatment of acetaminophen overdose. Am J Health Syst Pharm 1999;56:1081-91; quiz 1091-3.

20. Chiew AL, Fountain JS, Graudins A, Isbister GK, Reith D, Buckley NA. Summary statement. New guidelines for the management of paracetamol poisoning in Australia and New Zealand. Med J Aust 2015;203:215-8.

21. Kanter MZ. Comparison of oral and i.v. acetylcysteine in the treatment of acetaminophen poisoning. Am J Health Syst Pharm 2006;63:1821-7.

22. Keays R, Harrison PM, Wendon JA, Forbes A, Gove C, Alexander GJ et al. Intravenous acetylcysteine in paracetamol induced fulminant hepatic failure: a prospective controlled trial. BMJ 1991;303:1026.

23. Blackford MG, Felter T, Gothard MD, Reed MD. Assessment of the clinical use of intravenous and oral $\mathrm{N}$-acetylcysteine in the treatment of acute acetaminophen poisoning in children: a retrospective review. Clin Ther 2011;33:1322-30.

24. Daly FF, Fountain JS, Murray L, Graudins A, Buckley NA; Panel of Australian and New Zealand clinical toxicologists. Guidelines for the management of paracetamol poisoning in Australia and New Zealand--explanation and elaboration. A consensus statement from clinical toxicologists consulting to the Australasian poisons information centres. Med J Aust 2008;188:296-301.

25. Smilkstein MJ. Acetaminophen. In: Goldfrank LR (ed). Goldfrank's Toxological Emergencies, ed 6. Stamford: Conn, Appleton \& Lange, 1998;547.

26. Hendrickson RG, McKeown NJ. Acetaminophen. In: Marx JA (ed). Rosen's Emergency Medicine - Concepts and Clinical Practice, ed. 8. Philadelphia: Saunders, 2013;1961. 